\title{
Non-Thermal Plasma Can Be Used in Disinfection of Scots Pine (Pinus sylvestris L.) Seeds Infected with Fusarium oxysporum
}

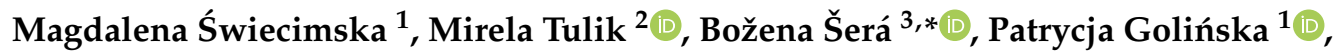 \\ Juliána Tomeková ${ }^{4}$, Veronika Medvecká ${ }^{4} \mathbb{D}$, Helena Bujdáková ${ }^{5}$, Tomasz Oszako ${ }^{6} \mathbb{D}$, \\ Anna Zahoranová ${ }^{4}$ and Michal Šerý ${ }^{7}$ \\ 1 Department of Microbiology, Nicolaus Copernicus University, Lwowska 1, 87-100 Torun, Poland; \\ mswieci@umk.pl (M.Ś.); golinska@umk.pl (P.G.) \\ 2 Department of Forest Botany, Warsaw University of Life Sciences (SGGW-WULS), Nowoursynowska 159, \\ 02-776 Warsaw, Poland; mtulik@wl.sggw.pl \\ 3 Faculty of Natural Sciences, Department of Landscape Ecology, Comenius University in Bratislava, \\ Ilkovičova 6, 84215 Bratislava, Slovak Republic \\ 4 Faculty of Mathematics, Physics and Informatics, Department of Experimental Physics, Comenius \\ University in Bratislava, Mlynská dolina, 84248 Bratislava, Slovak Republic; \\ juliana.tomekova@gmail.com (J.T.); medvecka.veronika@gmail.com (V.M.); zahoranova1@uniba.sk (A.Z.) \\ 5 Faculty of Natural Sciences, Department of Microbiology and Virology, Comenius University in Bratislava, \\ Ilkovičova 6, 84215 Bratislava, Slovak Republic; helena.bujdakova@uniba.sk \\ 6 Institute of Forest Research, Forest Protection Department, Braci Leśnej 3, 05-090 Sękocin Stary, Poland; \\ t.oszako@ibles.waw.pl \\ 7 Faculty of Education, Department of Physics, University of South Bohemia, Jeronýmova 10, \\ 37115 České Budějovice, Czech Republic; kyklop@pf.jcu.cz \\ * Correspondence: bozena.sera@uniba.sk
}

Received: 25 June 2020; Accepted: 31 July 2020; Published: 1 August 2020

\begin{abstract}
The aim of this study was to use diffuse coplanar surface barrier discharge (DCSBD) non-thermal plasma for the disinfection of pine seed surfaces infected with Fusarium oxysporum spores. Artificially infected seeds of Scots pine (Pinus sylvestris L.) were treated with plasma for the following exposure times: $1 \mathrm{~s}, 3 \mathrm{~s}, 5 \mathrm{~s}, 10 \mathrm{~s}, 15 \mathrm{~s}, 20 \mathrm{~s}, 30 \mathrm{~s}$, and $60 \mathrm{~s}$, and subsequently germinated on agar medium in Petri dishes at room temperature for the estimation of seed germination and disinfection effect of plasma treatment. Results of the treated samples were compared to the control samples, which were prepared as follows: seeds uninfected and non-treated with plasma (first control); seeds infected with F. oxysporum and non-treated with plasma (second control); and seeds infected with F. oxysporum, non-treated with plasma, but sterilized with $30 \%$ perhydrol (third control). Obtained results indicate that $3 \mathrm{~s}$ plasma treatment was an optimal time to inhibit F. oxysporum growth, and at the same time, increase the seed germination. In addition, our results are the first to show the practical application of non-thermal plasma in disinfecting infected Scots pine seeds and improving their germination. According to the results of this study, non-thermal plasma can serve as a seed surface disinfectant in the regeneration of different pine species.
\end{abstract}

Keywords: fungal disease; plant pathogen; seed germination; pine; non-thermal plasma treatment

\section{Introduction}

Scots pine (Scotch pine, Pinus sylvestris L.) is the most common conifer of the Pinaceae family and gymnosperms growing in the Northern Hemisphere. It is a valuable and commercially important 
tree in Europe. Pine trees are usually grown from seeds in specialized forest nurseries. The most important time for disease control is early in the seedling life. Damping-off is a common disease problem in seedbeds. Damping-off fungi (e.g., Fusarium sp., Alternaria sp., Botrytis sp., Rhizoctonia solani, Cylindrocarpon sp., and fungus-like Phytophtora sp. or Pythium sp.) can attack the seeds, the emerging seedlings, and the roots of first year seedlings. Fungal attacks are often fatal and can sharply reduce the seed germination or even eliminate seedling establishment [1]. Many plant fungal diseases are transmitted through seeds and fruits [2,3].

Pine seeds should be planted promptly after stratification. If the seed is allowed to dry out, dormancy may be triggered again and the efforts taken can be wasted [1]. Many seed stimulants such as phosphorus, potassium, microelements, hormones, and bacteria can be used for improving germination and the health of growing plants. Recently, non-thermal plasma treatment has been studied for seed surface disinfections and to enhance germination [4-6]. It was found that non-thermal plasma treatment can be used in the agricultural industry to improve/increase the seed germination of various plant species including winter wheat, brown mustard, altaic flax, rape, hemp, maize, and soybean [7-13], and for seed surface disinfections [6,12,14,15].

To date, a few papers have dealt with the non-thermal plasma treatment of tree species. Growth characteristics of conifers [16-18] and broadleaf tree species [19-21] after a physical treatment of seeds have been studied.

Diffuse coplanar surface barrier discharge (DCSBD) plasma is a kind of non-thermal plasma that can be easily generated at atmospheric pressure in ambient air. This is possible due to the special design of the electrode system and the dielectric barrier properties [22]. This type of plasma source does not need to use vacuum systems or expensive gases to generate plasma. Therefore, it is suitable for in-line treatment for various materials. DCSBD plasma has already been studied as a suitable method/technique of increasing the surface energy, activation, and cleaning of polymer surfaces and other materials. DCSBD plasma is non-equilibrium, consisting of many kinds of reactive particles, charged particles, UV radiation, radicals, metastable particles, and various gaseous products of plasma-chemical reactions. Non-equilibrium plasma does not damage heat-sensitive material such as seeds because the temperature of the heavy particles is not high. Therefore, DCSBD plasma research is now focused on the estimation of the efficacy of improved seed germination and inactivation of mycotoxins on the seed surface.

DCSBD plasma treatment has been used in studies on sterilization of polylactide (PLA) surface contaminated with Escherichia coli and Staphylococcus aureus and Penicillium chrysogenum, Cladosporium cladosporioides, Aspergillus fumigatus, and Fusarium culmorum [23] as well as wheat seed surface contaminated with Aspergillus clavatus, A. flavus, Fusarium culmorum, F. nivale, and Trichothecium roseum [24]. Testing this process on Monterey pine (P. radiata D. Don) seeds infected with F. circinatum was performed with DCSBD plasma treatment for $0 \mathrm{~s}, 5 \mathrm{~s}, 10 \mathrm{~s}, 60 \mathrm{~s}, 180 \mathrm{~s}$, and $300 \mathrm{~s}$ [15]. Infected seeds treated for $60 \mathrm{~s}$ or more were free of viable F. circinatum inoculum, but germination of the treated seeds was inhibited. DCSBD plasma treatment affected seed germination only with short exposure times. According to Šerý et al. [25], the useful times of DCSBD plasma treatment of Black pine ( $P$. nigra Arnold) seeds were $1 \mathrm{~s}, 3 \mathrm{~s}$ and $5 \mathrm{~s}$, as these times preserved the viable functions of the tested seeds. These treatment times significantly improved the measured parameters: germination index (1 s), length of seedling (1 s, $3 \mathrm{~s})$, and seedling vigor index I (1 s, $3 \mathrm{~s})$.

Environmentally safe methods for testing biological materials are desirable, which is why our research has the goal to evaluate the effect of DCSBD plasma treatment on the surface disinfection of Scots pine seeds compared to conventional disinfection agents (e.g., chlorine compounds, ethanol, hydrogen peroxide). In this work, F. oxysporum, as a model fungal pathogen of seedlings and roots of many plants including Scots pine [26-28] was chosen. F. oxysporum is one of the common plant pathogens that can be transmitted due to infected seeds. 


\section{Materials and Methods}

\subsection{Plant and Fungal Material}

Seeds of Scots pine (Pinus sylvestris L.) of Polish provenance were collected in 2019 from the Forest District Chojnów, Pilawa, Mazowieckie voivodeship $\left(52^{\circ} 02^{\prime} 19^{\prime} \mathrm{N}, 21^{\circ} 05^{\prime} 20^{\prime \prime} \mathrm{E}\right)$ and supplied by the Institute of Forest Research in Sekocin Stary near Warsaw, Poland. Their germination was estimated at $76 \%$ and the weight of a thousand seeds was $542.40 \mathrm{mg}$. Only visually healthy and undamaged Scots pine seeds with seed coat and without flight were used. Each test and control variant contained 150 Scots pine seeds.

The fungal soil born Pinus sylvestris pathogen, Fusarium oxysporum (Schlechtendal ex Fr.) isolate 342 derived from pine root, was obtained from the Bank of Plant Pathogens, Institute of Plant Protection, National Research Institute, Poznań, Poland and used in the experiments.

\subsection{Seed Inoculation}

Scots pine seeds, before inoculation with F. oxysporum spores, were surface disinfected in $30 \%$ $\mathrm{H}_{2} \mathrm{O}_{2}$ for $20 \mathrm{~min}$. Subsequently, seeds were rinsed six times in sterile distilled water and aseptically air

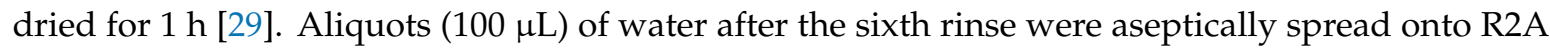
(Becton Dickinson) and PDA (Potato Dextrose Agar, Becton Dickinson, NJ, USA) to confirm surface sterilization of seeds from bacteria and fungi, respectively. Both the preparation of spore suspension and the seed inoculation were performed following the procedure described by Evira-Recuenco [30], with minor modifications. Briefly, the F. oxysporum spore suspension was prepared by washing a 7-day-old culture growing on PDA (Potato Dextrose Agar, Becton Dickinson, NJ, USA) at $28{ }^{\circ} \mathrm{C}$ with sterile saline solution. Fungal spore concentration was counted using a hemocytometer, diluted to a concentration of $10^{6}$ spores/mL and then sonicated. Seeds were inoculated with the fungal spore suspension in $50 \mathrm{~mL}$ centrifuge tubes and incubated at $28^{\circ} \mathrm{C}$ in gentle shaking conditions for $20 \mathrm{~min}$. The seeds were separated from solution and air dried in a laminar hood overnight.

Both the surface sterilized seeds and the ones treated with sterile saline solution were used as the negative control (Control 1). Surface sterilized seeds inoculated with fungal spores were used as the positive control (Control 2). Additionally, seeds inoculated with fungal spores were treated with $30 \% \mathrm{H}_{2} \mathrm{O}_{2}$ for $20 \mathrm{~min}$ (Control 3) to compare the effectiveness of chemical and non-thermal plasma disinfection methods.

\subsection{Description of Diffuse Coplanar Surface Barrier Discharge (DCSBD)}

Diffuse coplanar surface barrier discharge (DCSBD), as a special type of the dielectric barrier discharge, generates low-temperature plasma at atmospheric pressure in a thin layer on the dielectric surface [31]. Configuration of the DCSBD plasma with the experimental setup of the plasma treatment is shown in Figure 1. Many parallel electrodes situated at the bottom side of the ceramic $\mathrm{Al}_{2} \mathrm{O}_{3}$ plate and cooled by the oil are powered by a high voltage sinusoidal signal. Alternating-current (AC) signal with an amplitude of approximately $20 \mathrm{kV}$ peak to peak with a frequency of $14 \mathrm{kHz}$ was generated by the HV generator LIFETECH VF 700 (Lifetech, Czech Republic). Plasma created in a thin layer is composed of many micro-discharges moving on the ceramic surface along the electrodes. Electrodes are not in contact with the plasma, which prolongs their life span. 


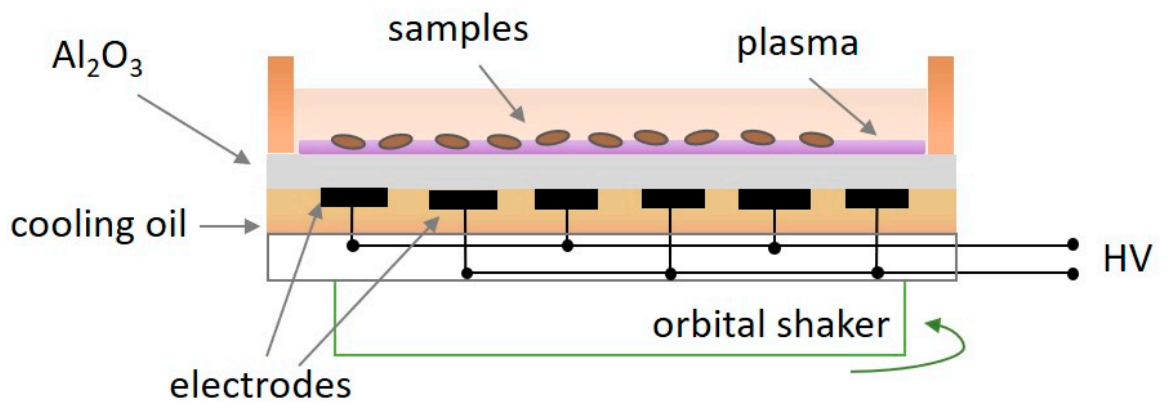

Figure 1. Configuration of the DCSBD plasma and experimental setup of the plasma treatment.

\subsection{Plasma Treatment}

DCSBD plasma treatment (Figure 1) was performed at different exposure times: 1, 3, 5, 10, 15, 20, 30 , and $60 \mathrm{~s}$. After switching on the plasma at the applied power of $400 \mathrm{~W}$, seeds were put into the plasma for the specific time and moved rotationally. Rotational movement of the seeds was carried out by the orbital shaker, which moved the whole discharge panel at the frequency of $330 \mathrm{rpm}$ for the homogeneous plasma treatment of the seeds.

\subsection{Seed Cultivation}

Infected seeds were treated with plasma and directly germinated onto a surface of Yeast extract Peptone Dextrose (YPD) agar (Becton Dickinson, NJ, USA), a solid medium suitable for the cultivation of fungi, in a sterile Petri dishes. Thirty seeds were aseptically placed on the surface of the dish with YPD agar. The seed germination was run under controlled growing conditions $\left(28^{\circ} \mathrm{C}\right.$, in darkness for 12 days).

During the experiment, some characteristics were assessed [15,25]:

1. disinfection efficiency (DE): percentage of seed without mold spreading around seeds,

2. seed germination (SG): percentage of germinated seeds (germination is positive if a $1 \mathrm{~mm}$ radicle occurs),

3. germination rate (GR): the percentage ratio of germinated seeds at the beginning (4th day) to germinated seeds at the end (12th day) of the seed germination,

4. germination index (GI): the total number of germinated seeds to the respective day (4th, 7 th, 9th, and 12 th day) of germination.

\subsection{Statistical Analysis}

Data were analyzed using the STATISTICA software (Statistica 13, StatSoft Inc. Tulsa, OK, USA) at the significance level of 0.05. Logarithmic transformation $(y=\log (x))$ of the basic data was used for normalization before the analysis. One way analysis of variance (ANOVA) was used to evaluate the influence of the plasma treatment on characteristics of seed germination and surface disinfection. The detailed testing of experimental variances from each other was done using Tukey's honest significant difference (HSD) test.

\subsection{Morphological Observation}

Morphological observations of seeds and seedlings after different exposure time to non-thermal plasma treatment and controls were carried out with the naked eye. The following characteristics were recorded: seed coat color, external structure of the seedlings, amount and color of cotyledons, shoots, and fine roots. 


\section{Results}

\subsection{Effect of Plasma Treatment on Seed Disinfection and Germination}

It was found that all plasma treatments (for different exposure times) showed relatively high values of disinfection efficiency (more than 85\%) during all days of seed germination (Figure 2). The highest disinfection efficiencies were observed after 3 s, 5 s, 15 s, 20 s, 30 s, and 60 s of plasma treatment with no statistical difference between these six treatments and Control 1 and 3, which were subsequently different from Control 2 (Table 1).

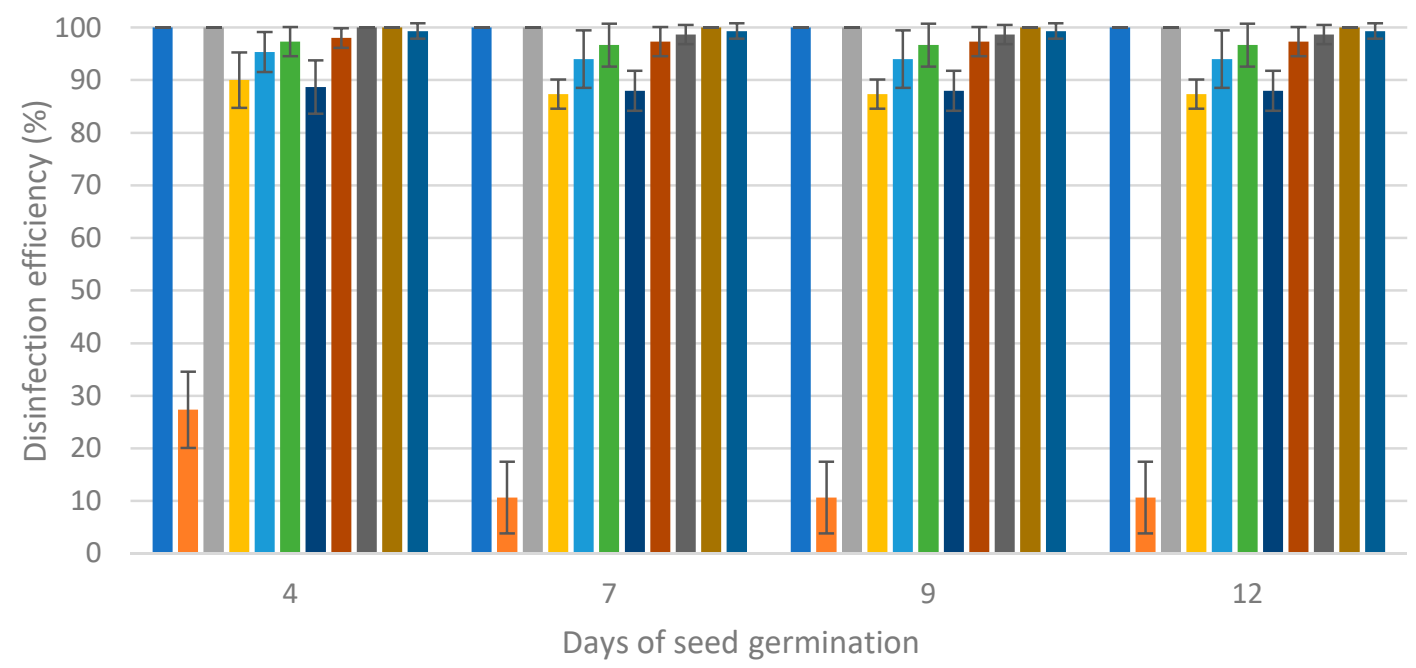

$\square$ control $1 \square$ control $2 \square$ control $3 \square 1 \mathrm{sec} \square 3 \mathrm{sec} \square 5 \mathrm{sec} \square 10 \mathrm{sec} \square 15 \mathrm{sec} \square 20 \mathrm{sec} \square 30 \mathrm{sec} \square 60 \mathrm{sec}$

Figure 2. Disinfection efficiency (\%) of Scots pine seeds inoculated with F. oxysporum exposed to different times of non-thermal plasma treatment after the 4th, 7th, 9th, and 12th days of fungal incubation. Control 1: seeds uninfected and non-treated with plasma; control 2: seeds infected with F. oxysporum and non-treated with plasma; control 3: seeds infected with F. oxysporum, non-treated with plasma, but sterilized with $30 \%$ perhydrol.

Table 1. Effect of diffuse coplanar surface barrier discharge (DCSBD) plasma treatment on Scots pine seeds infected with F. oxysporum. Characteristics measured (mean and standard deviation (SD) are given) at the end of experimental cultivation (12th day). Tukey's HSD (Honest Significant Difference) test was used. Significant differences at $p<0.05$ are indicated by different letters. Control 1, control 2 , and control 3, see Figure 2.

\begin{tabular}{|c|c|c|c|c|c|c|c|c|c|c|c|c|}
\hline & \multicolumn{3}{|c|}{ Seed Germination (\%) } & \multicolumn{3}{|c|}{ Germination Rate (\%) } & \multicolumn{3}{|c|}{ Germination Index } & \multicolumn{3}{|c|}{ Disinfection Efficiency (\%) } \\
\hline control 1 & 76.00 & 13.00 & ad & 65.78 & 12.80 & a & 5.11 & 1.31 & ae & 100.00 & 0.00 & a \\
\hline control 3 & 95.33 & 3.80 & ad & 95.78 & 2.96 & a & 11.34 & 1.54 & $b$ & 100.00 & 0.00 & a \\
\hline $1 \mathrm{~s}$ & 94.00 & 1.49 & ad & 97.14 & 5.87 & a & 9.27 & 0.25 & bc & 87.33 & 2.79 & c \\
\hline $10 \mathrm{~s}$ & 90.67 & 4.35 & ad & 97.69 & 3.44 & a & 8.95 & 0.55 & bcd & 88.00 & 3.80 & c \\
\hline $15 \mathrm{~s}$ & 70.00 & 29.91 & bd & 70.91 & 15.58 & a & 4.60 & 1.98 & e & 97.33 & 2.79 & a \\
\hline $20 \mathrm{~s}$ & 43.33 & 30.09 & $\mathrm{~b}$ & 73.15 & 20.64 & a & 2.40 & 1.70 & $\mathrm{f}$ & 98.67 & 1.83 & a \\
\hline $30 \mathrm{~s}$ & 6.00 & 4.94 & c & 30.00 & 44.72 & $b$ & 0.30 & 0.27 & $\mathrm{f}$ & 100.00 & 0.00 & a \\
\hline $60 \mathrm{~s}$ & 2.00 & 1.83 & c & 0.00 & 0.00 & $b$ & 0.05 & 0.05 & $\mathrm{f}$ & 99.33 & 1.49 & a \\
\hline
\end{tabular}

All data including the sets of the three controls, measured at the end (12th day) of the experiment, are summarized in Table 1. The highest seed germination was observed when seeds were treated with plasma for $3 \mathrm{~s}$ on all measurement days while the lowest with plasma treatment for $60 \mathrm{~s}$ (Figure 3). 
The highest seed germination rate (GR) after seven days of cultivation was found when seeds were treated with plasma for $3 \mathrm{~s}$. In contrast, the highest GR after nine and 12 days of cultivation was observed for seeds treated with plasma for $10 \mathrm{~s}$ in both cases (Figure 4). The germination index calculated for the end of the cultivation period (12th day) was highest when seeds were treated with plasma for $3 \mathrm{~s}$ (Table 1). The sterilization effectiveness was at the level of $95.3 \%$ on the 4 th while on the 7 th, 9th, and 12th day of seed cultivation, the level of sterilization effectiveness was at $94.0 \%$. A total of $14.0 \%$ of the seeds germinated on the fourth day, while $86.0 \%$ germinated on the seventh, and $96.7 \%$ germinated on the twelfth day of seed cultivation (Figure 5).

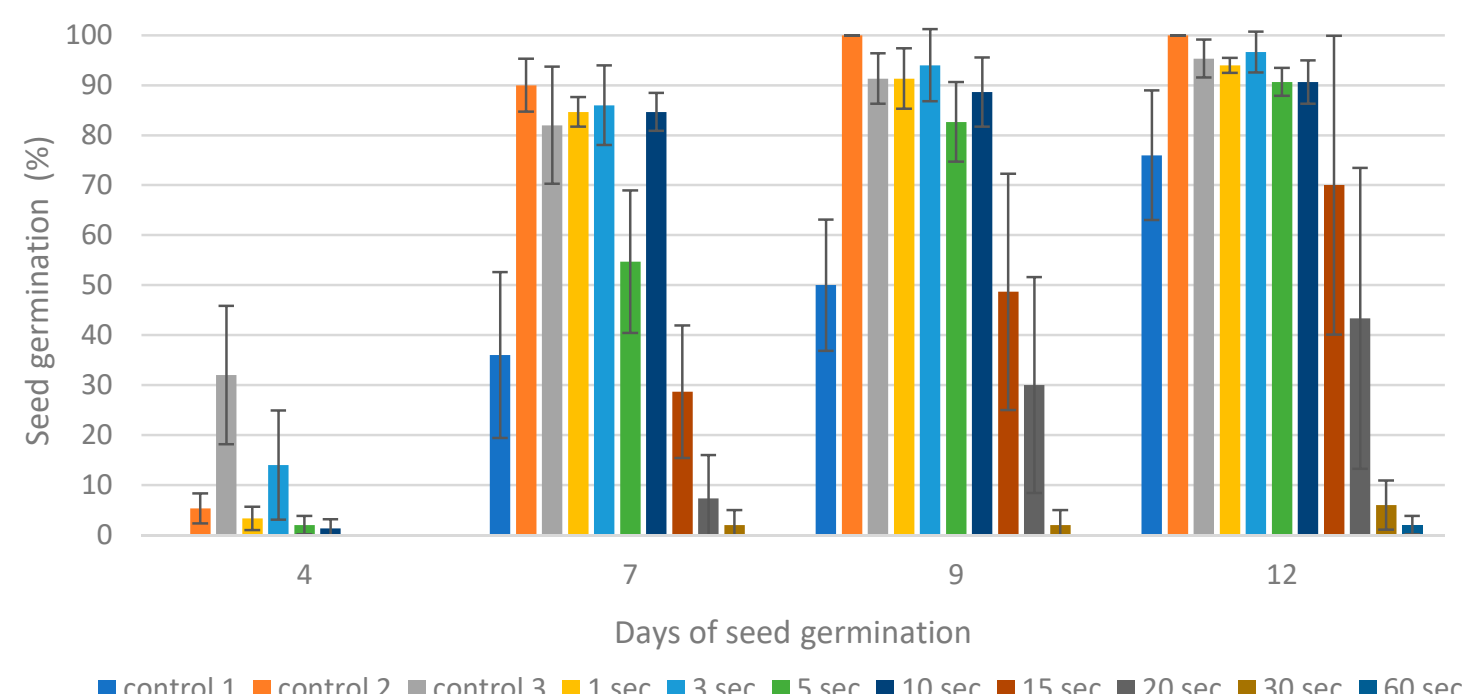

Figure 3. The percentage of Scots pine seed germination exposed to different times of non-thermal plasma treatment after the 4 th, 7 th, 9 th, and 12 th days of seed germination. Control 1, control 2, and control 3, see Figure 2.

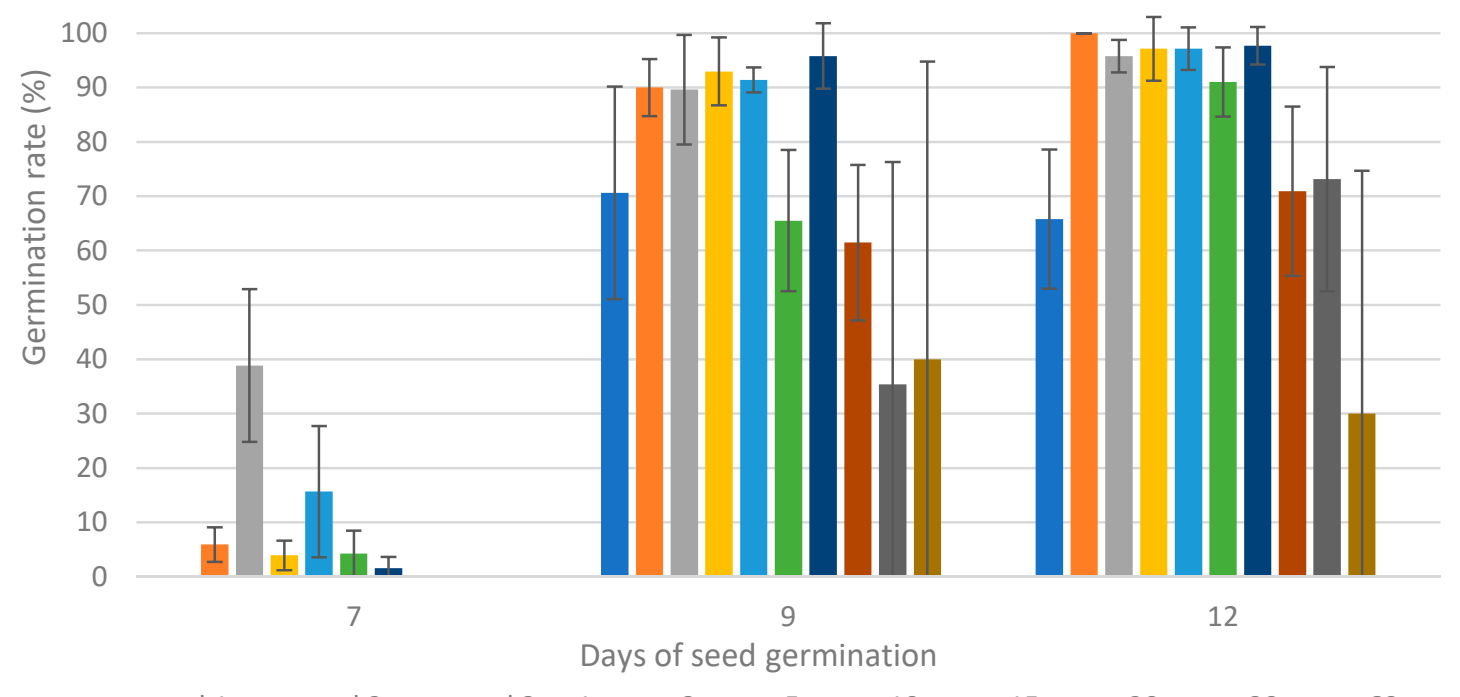

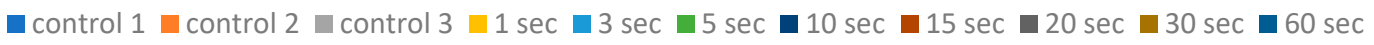

Figure 4. Germination rate of Scots pine seeds exposed to different times of non-thermal plasma treatment after the 4th, 7th, 9th, and 12th days of seed germination. Control 1, control 2, and control 3, see Figure 2. 


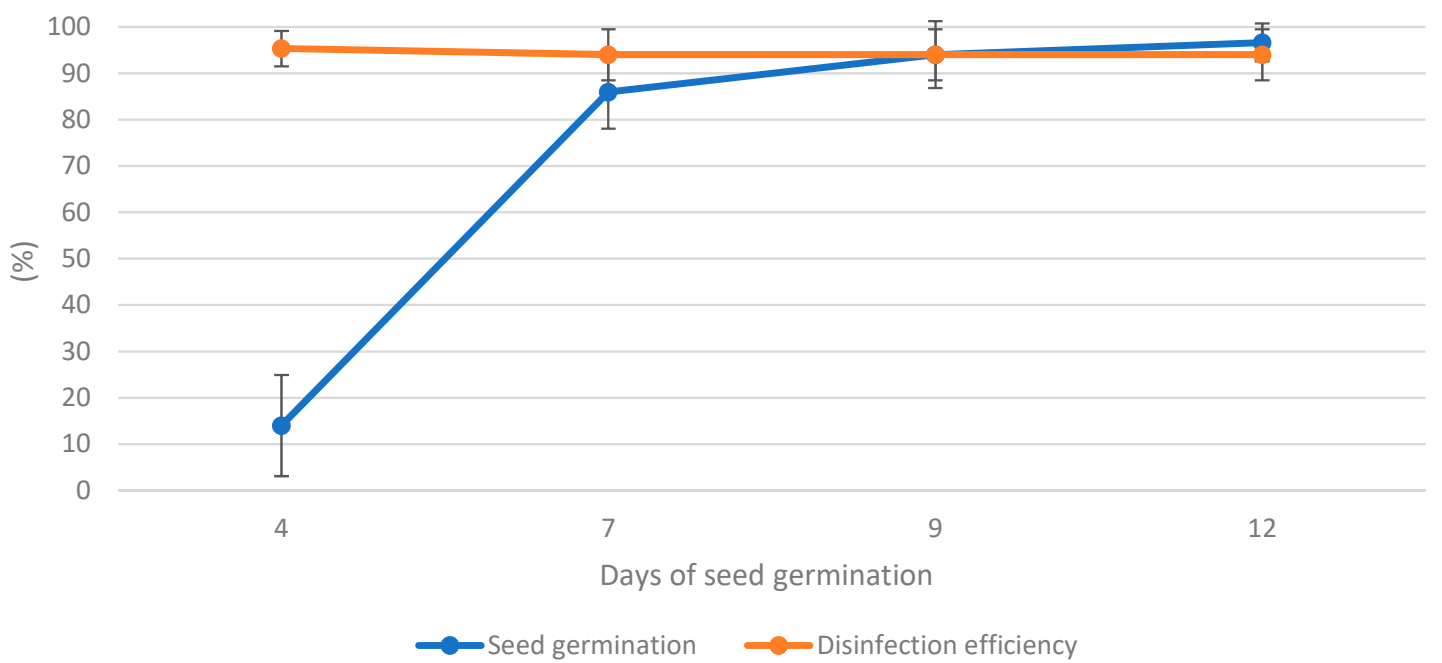

Figure 5. Scots pine seed germination and seed surface disinfection after $3 \mathrm{~s}$ of non-thermal plasma treatment. Observations after the 4 th, 7 th, 9 th, and 12 th days of seed germination. More details are given in the Methods.

\subsection{Morphological Observation}

Although the test exposure times of seeds to non-thermal plasma were found to be non-lethal for them, their extended germination time was observed when compared to the control ones. The use of non-thermal plasma did not affect the color change of the seed coat. The external structure of the seedlings that grew from seeds treated with non-thermal plasma did not differ from the control ones. The number of green cotyledons varied from four to six, and the shoots and fine roots were all well recognized.

\section{Discussion}

Among the microbial diseases of plants, plant pathogenic fungi are dominant causal agents leading to severe yield loss in a number of crop plants, vegetables, fruits, and in forestry [32]. To date, many chemical products have been effectively used in the control of plant diseases caused by a wide-range of fungi [33]. Although universal application of broad spectrum fungicides definitely helps in controlling the fungal diseases in plants, at the same time, there have been several reports suggesting that these fungicides have been posing severe hazardous effects on the environment for several years. Moreover, extensive use of chemical fungicides has also resulted in resistance development in many plant pathogenic fungi against such fungicides [34]. Furthermore, loss in soil fertility is another major concern [35]. In this context, the search for novel, effective, and environmentally-friendly solutions for the reduction in plant pathogenic fungi is a prime area of research [36]. One such solution area is the development of the seed disinfection methods without the use of chemical fungicides [37].

Scientists are increasingly interested in using non-thermal plasma for the disinfection of plant seeds and bulbs [38]. The lethal effects of non-thermal plasma on fungi, viruses as well as vegetative cells and spores of bacteria have been proven by Kordas et al. [6], Terrier et al. [39], Klämpfl et al. [40], Ryu et al. [41], Tyczkowska-Sieroń and Markiewicz [42], Pignata et al. [43], and Sakudo et al. [44]. The antifungal effects of non-thermal plasma treatment against the fungus, F. oxysporum on Scots pine seeds, was confirmed by our studies. After $1 \mathrm{~s}$ of treatment with plasma, more than $80 \%$ of fungal growth was inhibited. Little research has previously been done on the disinfection of conifer seeds using this method Most of the available data relates to the seeds of cereals and crops. The disinfecting effect of plasma on seeds has been confirmed in studies by many authors. Kordas and coauthors [6] studied the use of low-thermal plasma as a disinfectant method for winter wheat grain. They found that the use of this plasma for a $10 \mathrm{~s}$ exposure time resulted in a reduction of the seed-born fungi and positively affected the basic values determining seed lot quality as well as the development of winter 
wheat in the initial growth stage [6]. Other authors have evaluated antifungal plasma effect against Aspergillus sp. and Penicillum sp. using seeds of chickpeas, corn, barley, oats, wheat, and lentils, and showed that a significant reduction in the growth of the studied fungi was achieved after $15 \mathrm{~min}$ of exposure [45]. Zahoranová et al. [12] observed growth inhibition of Alternaria alternata, Aspergillus flavus, and F. culmorum on maize seeds after treatment with plasma while Kang et al. [46] and Ochi et al. [47] reported the inhibition of $F$. fujikuroi growth on rice seeds. Other authors $[45,48,49]$ have also used non-thermal plasma for the sterilization of legumes, cereals, and nut seeds. Simultaneously, they observed that its use positively affected the seed growth and plant development..

Moreover, Go et al. [50] reported that exposure of postharvest peppers to non-thermal plasma for $90 \mathrm{~s}$ resulted in $50 \%$ reduction of the development of $F$. oxysporum. Avramidis et al. [51] observed that a $60 \mathrm{~s}$ exposure of F. culmorum and Ascochyta pinodella to non-thermal plasma caused cell wall and membrane damage and cytoplasmic leakage in these fungi. Non-thermal plasma destroys microorganisms by the synergistic action of reactive particles, ionized ions, electrons, and UV radiation $[52,53]$.

The effectiveness of using non-thermal plasma as a sterilizing and plant growth promoting agent varies, depending on the gas used in the apparatus and the type of microorganisms that appear on the sterilized material [44]. However, it should also be mentioned that the prolonged plasma exposure time, which is necessary to inhibit the growth of certain pathogens, may damage the seeds and weaken their germination [12,15]. Until now, the impact of plasma on the seed germination of Scots pine has not been well studied yet. In the research of Šerá et al. [15], the time necessary to inhibit the growth of F. circinatum was one minute and caused complete inhibition of seed germination. In our research, seeds exposed to plasma for longer than $10 \mathrm{~s}$ had their germination lowered when compared to non-treated seeds.

For commercial use of non-thermal plasma for seed sterilization, it is necessary to develop an optimal exposure time that will provide a desirable effect without any damage to the seeds. In any case, plasma is a promising technology that will help to establish a successful strategy to regenerate trees through seeds.

\section{Conclusions}

The results of this work demonstrate the ability of using non-thermal atmospheric plasma for effective and rapid disinfection of Scots pine seeds to prevent the spread of the plant pathogen, F. oxysporum. Short exposure time to this factor caused stimulation in seed germination compared to untreated seeds. However, exposure longer than $10 \mathrm{~s}$ inhibited their germination. This research is the first report on the use of non-thermal plasma treatment for the disinfection of Scots pine seeds and for the estimation of seed germination and seedling growth. It seems that non-thermal plasma may be used in the regeneration of Scots pine and other woody species through seeds. To consider this method as an alternative to chemical disinfection, more research should be performed with the use of other fungal species to optimize plasma treatment conditions.

Author Contributions: Conceptualization, B.Š., P.G., and T.O.; Methodology, B.Š., M.Ś., H.B., and M.T.; Formal analysis, M.Ś. and M.T.; Investigation, M.Ś., M.T., V.M., and J.T.; Data curation, B.Š.; Writing—original draft preparation, M.Ś.; Writing—review and editing, P.G., B.Š., M.Ś., M.T., A.Z., and M.Š.; Visualization, M.Š.; Supervision, B.Š. and P.G.; Project administration, A.Z.; Funding acquisition, M.Ś. and A.Z. All authors have read and agreed to the published version of the manuscript.

Funding: This research was supported by the Erasmus+ program (agreement no. 502811/ERA+047730/SMP) and the Slovak Research and Development Agency (contract no. APVV-16-0216).

Conflicts of Interest: The authors declare no conflicts of interest. 


\section{References}

1. Harrington, C.A. G77-380 Growing Conifers from Seed. In Historical Materials from University of Nebraska-Lincoln Extension; University of Nebraska-Lincoln: Lincoln, NE, USA, 1977; p. 851. Available online: http://digitalcommons.unl.edu/extensionhist/851 (accessed on 11 February 2020).

2. Mancini, V.; Romanazzi, G. Seed treatments to control seedborne fungal pathogens of vegetable crops. Pest Manag. Sci. 2014, 70, 860-868. [CrossRef] [PubMed]

3. Zhang, S.; Zheng, Q.; Xu, B.; Liu, J. Identification of the fungal pathogens of postharvest disease on peach fruits and the control mechanisms of Bacillus subtilis JK-14. Toxins 2019, 11, 322. [CrossRef] [PubMed]

4. Thirumdas, R.; Kothakota, A.; Annapure, U.; Siliveru, K.; Blundell, R.; Gatt, R.; Valdramidis, V.P. Plasma activated water (PAW): Chemistry, physico-chemical properties, applications in food and agriculture. Trends Food Sci. Tech. 2018, 77, 21-31. [CrossRef]

5. Kaushik, N.K.; Ghimire, B.; Li, Y.; Adhikari, M.; Veerana, M.; Kaushik, N.; Jha, N.; Adhikari, B.; Lee, S.J.; Masur, K.; et al. Biological and medical applications of plasma-activated media, water and solutions. Biol. Chem. 2019, 400, 39-62. [CrossRef]

6. Kordas, L.; Pusz, W.; Czapka, T.; Kacprzyk, R. The effect of low-temperature plasma on fungus colonization of winter wheat grain and seed quality. Pol. J. Environ. Stud. 2015, 24, 433-438.

7. Dubinov, A.E.; Kozhayeva, J.P.; Zuimatch, E.A. Changing germination rate of brown mustard seeds after treatment with plasmas of nanosecond electric discharges. IEEE Trans. Plasma Sci. 2017, 45, $294-300$. [CrossRef]

8. Dubinov, A.E.; Kozhayeva, J.P.; Zuimatch, E.A. Scarification of altaic flax seeds with high-power UV radiation generated by plasma of nanosecond electric discharges. IEEE Trans. Plasma Sci. 2019, 47, 69-75. [CrossRef]

9. Puac, N.; Gherardi, M.; Shiratani, M. Plasma agriculture: A rapidly emerging field. Plasma Process Polym. 2018, 15, e1700174. [CrossRef]

10. Puligundla, P.; Kim, J.W.; Mok, C. Effect of corona discharge plasma jet treatment on decontamination and sprouting of rape seed (Brassica napus L.) seeds. Food Control 2017, 71, 376-382. [CrossRef]

11. Šerá, B.; Šerý, M.; Gavril, B.; Gajdova, I. Seed germination and early growth responses to seed pre-treatment by non-thermal plasma in hemp cultivars (Cannabis sativa L.). Plasma Chem. Plasma Process. 2017, 37, $207-221$. [CrossRef]

12. Zahoranová, A.; Hoppanová, L.; Šimončicová, J.; Tueková, Z.; Medvecká, V.; Hudecová, D.; Kaliňáková, B.; Kováčik, D.; Černák, M. Effect of cold atmospheric pressure plasma on maize seeds: Enhancement of seedlings growth and surface microorganisms inactivation. Plasma Chem. Plasma Process. 2018, 38, 969-988. [CrossRef]

13. Zhang, J.J.; Jo, J.O.; Huynh, D.L.; Mongre, R.K.; Ghosh, M.; Singh, A.K.; Lee, S.B.; Mok, Y.S.; Hyuk, P.; Jeong, D.K. Growth-inducing effects of argon plasma on soybean sprouts via the regulation of demethylation levels of energy metabolism-related genes. Sci. Rep. 2017, 7, 41917. [CrossRef] [PubMed]

14. Mitra, A.; Li, Y.F.; Klämpfl, T.G.; Shimizu, T.; Jeon, J.; Morfill, G.E.; Zimmermann, J.L. Inactivation of surface-borne microorganisms and increased germination of seed specimen by cold atmospheric plasma. Food Bioprocess Technol. 2014, 7, 645-653. [CrossRef]

15. Šerá, B.; Zahoranová, A.; Bujdáková, H.; Šerý, M. Disinfection from pine seeds contaminated with Fusarium circinatum Nirenberg \& O'Donnell using non-thermal plasma treatment. Rom. Rep. Phys. 2019, 71, 70.

16. Gavrilova, O.I.; Pitukhin, A.V.; Zhuravleva, M.V.; Gostev, K.V.; Gostev, V.A. Influence of cold plasma spray on germinating ability of seeds and growth of softwood seedlings. In Proceedings of the International Multidisciplinary Scientific GeoConference-SGEM, 16th International Multidisciplinary Scientific Geoconference (SGEM 2016), Albena, Bulgaria, 30 June 2016; pp. 547-554.

17. Nelson, S.O.; Krugman, S.L.; Stetson, L.E.; Belcher, E.W.; Works, D.W.; Stone, R.B.; Pettibone, C.A.; Goodenough, J.L. Germination responses of pine seed to radiofrequency, infrared, and gas-plasma-radiation treatments. For. Sci. 1980, 26, 377-388. [CrossRef]

18. Pauzaite, G.; Malakauskiene, A.; Nauciene, Z.; Zukiene, R.; Filatova, I.; Lyushkevich, V.; Azarko, I.; Mildaziene, V. Changes in Norway spruce germination and growth induced by pre-sowing seed treatment with cold plasma and electromagnetic field: Short-term versus long-term effects. Plasma Process Polym. 2018, 15, e1700068. [CrossRef] 
19. Chao, L.; Walker, D.R. Effect of a magnetic field on the germination of apple, apricot and peach seeds. HortScience 1967, 2, 152-153.

20. Mildaziene, V.; Pauzaite, G.; Malakauskiene, A.; Zukiene, R.; Nauciene, Z.; Filatova, I.; Azharonok, V.; Lyushkevich, V. Response of perennial woody plants to seed treatment by electromagnetic field and low-temperature plasma. Bioelectromagnetics 2016, 37, 536-548. [CrossRef]

21. Zivkovic, S.; Puac, N.; Giba, Z.; Grubisic, D.; Petrovic, Z.L. The stimulatory effect of non-equilibrium (low temperature) air plasma pretreatment on light-induced germination of Paulownia tomentosa seeds. Seed Sci. Technol. 2004, 32, 693-701. [CrossRef]

22. Černák, M.; Černáková, L.I.; Hudec, I.D.; Kováčik, D.A.; Zahoranová, A. Diffuse Coplanar Surface Barrier Discharge and its applications for in-line processing of low-added-value materials. Eur. Phys. J. Appl. Phys. 2009, 47, 22806. [CrossRef]

23. Stepczyńska, M. Surface modification by low temperature plasma: Sterilization of biodegradable materials. Plasma Process Polym. 2016, 13, 1078-1086. [CrossRef]

24. Zahoranova, A.; Henselova, M.; Hudecova, D.; Kalinakova, B.; Kovacik, D.; Medvecka, V.; Cernak, M. Effect of cold atmospheric pressure plasma on the wheat seedlings vigor and on the inactivation of microorganisms on the seeds surface. Plasma Chem. Plasma Process. 2016, 36, 397-414. [CrossRef]

25. Šerý, M.; Zahoranová, A.; Kerdík, A.; Šerá, B. Seed germination of Black pine (Pinus nigra Arnold) after Diffuse Coplanar Surface Barrier Discharge plasma treatment. IEEE Trans. Plasma Sci. 2020, 48, 939-945. [CrossRef]

26. Machón, P.; Pajares, J.A.; Diez, J.J.; Alves-Santos, F.M. Influence of the ectomycorrhizal fungus Laccaria laccata on pre-emergence, post-emergence and late damping-off by Fusarium oxysporum and F. verticillioides on Stone pine seedlings. Symbiosis 2009, 49, 101-109. [CrossRef]

27. Martín-Pinto, P.; Pajares, J.; Díez, J. Pathogenicity of Fusarium verticillioides and Fusarium oxysporum on Pinus nigra seedlings in northwest Spain. For. Pathol. 2008, 38, 78-82. [CrossRef]

28. Anderson, I.C.; Campbell, C.D.; Prosser, J.I. Diversity of fungi in organic soils under a moorland-Scots pine (Pinus sylvestris L.) gradient. Environ. Microbiol. 2003, 5, 1121-1132. [CrossRef]

29. Redlak, K.; Dahm, H. The effect of ectendomycorrhizal fungi and diazotrophic bacteria on pine seedlings (Pinus sylvestris) in vitro. Sylwan 2001, 3, 81-92.

30. Evira-Recuenco, M.; Iturritxa, E.; Raposo, R. Impact of seed transmission on the infection and development of Pitch Canker disease in Pinus radiata. Forests 2015, 6, 3353-3368. [CrossRef]

31. Černák, M.; Rahel, J.; Kovacik, D.; Simor, M.; Brablec, A.; Slavicek, P. Generation of thin surface plasma layers for atmospheric-pressure surface treatments. Contrib. Plasma Phys. 2004, 44, 492-495. [CrossRef]

32. Kancelista, A.; Piegza, M.; Stolaś, J.; Witkowska, D. Wpływ grzybów rodzaju Trichoderma na wzrost patogennych grzybów strzępkowych w testach biotycznych na nietypowych źródłach węgla. Acta Sci. Pol. Biotechnologia 2009, 8, 3-14.

33. Karmiłowicz, E. The use of herbicides to regulate weeds in forest nurseries and crops in Poland. Folia For. Pol. Ser. A For. 2019, 61, 222-229. [CrossRef]

34. Okorski, A.; Pszczółkowska, A.; Oszako, T.; Nowakowska, J.A. Current possibilities and prospects of using fungicides in forestry. For. Res. Pap. 2015, 76, 191-206. [CrossRef]

35. Kumar, R.P.K.; Niharika, S.P.; Hemanth, G. Impact of fungicides on the growth and distribution of soil mycoflora in agriculture fields at Narasannapeta. IJSR 2017, 6, 2337-2347. [CrossRef]

36. Seipke, R.F.; Kaltenpoth, M.; Hutchings, M.I. Streptomyces as symbionts: An emerging and widespread theme? FEMS Microbiol. Rev. 2012, 36, 862-876. [CrossRef]

37. Adhikari, B.; Pangomm, K.; Veerana, M.; Mitra, S.; Park, G. Plant Disease Control by Non-Thermal Atmospheric-Pressure Plasma. Front. Plant Sci. 2020, 14. [CrossRef]

38. Laskowska, M.; Bogusławska-Wąs, E.; Kowal, P.; Hołub, M.; Dąbrowski, W. Skuteczność wykorzystania niskotemperaturowej plazmy w mikrobiologii i medycynie. Post. Mikrobiol. 2016, 55, 172-181.

39. Terrier, O.; Essere, B.; Yver, M.; Barthélémy, M.; Bouscambert-Duchamp, M.; Kurtz, P.; VanMechelen, D.; Morfin, F.; Billaud, G.; Ferraris, O.; et al. Cold oxygen plasma technology efficiency against different airborne respiratory viruses. J. Clin. Virol. 2009, 45, 119-124. [CrossRef]

40. Klämpfl, T.G.; Isbary, G.; Shimizu, T.; Li, Y.F.; Zimmermann, J.L.; Stolz, W.; Schlegel, J.; Morfill, G.E.; Schmidt, H.U. Cold atmospheric air plasma sterilization against spores and other microorganisms of clinical interest. Appl. Environ. Microbiol. 2012, 78, 5077-5082. [CrossRef] 
41. Ryu, Y.H.; Kim, Y.H.; Lee, J.Y.; Shim, G.B.; Uhm, H.S.; Park, G.; Choi, E.H. Effects of background fluid on the efficiency of inactivating yeast with non-thermal atmospheric pressure plasma. PLoS ONE 2013, 8, e66231. [CrossRef]

42. Tyczkowska-Sieron, E.; Markiewicz, J. Inaktywacja grzybów z rodzaju Candida przy użyciu zimnej plazmy atmosferycznej-na drodze ku nowej metodzie eradykacji grzybic powierzchniowych. Med. Dośw. Mikrobiol. 2014, 66, 121-129.

43. Pignata, C.; D’Angelo, D.; Fea, E.; Gilli, G. A review on microbiological decontamination of fresh produce with nonthermal plasma. J. Appl. Microbiol. 2017, 122, 1438-1455. [CrossRef] [PubMed]

44. Sakudo, A.; Yagyu, Y.; Onodera, T. Disinfection and sterilization using plasma technology: Fundamentals and future perspectives for biological applications. Int. J. Mol. Sci. 2019, 20, 5216. [CrossRef] [PubMed]

45. Selcuk, M.; Oksuz, L.; Basaran, P. Decontamination of grains and legumes infected with Aspergillus spp. and Penicillum spp. by cold plasma treatment. Bioresour. Technol. 2008, 99, 5104-5109. [CrossRef] [PubMed]

46. Kang, M.H.; Pengkit, A.; Choi, K.; Jeon, S.S.; Choi, H.W.; Shin, D.B.; Choi, E.H.; Uhm, H.S.; Park, G. Differential inactivation of fungal spores in water and on seeds by ozone and arc discharge plasma. PLoS ONE 2015, 10, e0139263. [CrossRef]

47. Ochi, A.; Konishi, H.; Ando, S.; Sato, K.; Yokoyama, K.; Tsushima, S.; Yoshida, S.; Morikawa, T.; Kaneko, T.; Takahashi, H. Management of bakanae and bacterial seedling blight diseases in nurseries by irradiating rice seeds with atmospheric plasma. Plant Pathol. 2017, 66, 67-76. [CrossRef]

48. Basaran, P.; Basaran-Akgul, N.; Oksuz, L. Elimination of Aspergillus parasiticus from nut surface with low pressure cold plasma (LPCP) treatment. Food Microbiol. 2008, 25, 626-632. [CrossRef]

49. Jiang, J.; He, X.; Li, L.; Li, J.; Shao, H.; Xu, Q.; Ye, R.; Dong, Y. Effect of cold plasma treatment on seed germination and growth of wheat. Plasma Sci. Technol. 2014, 16, 54. [CrossRef]

50. Go, S.M.; Park, M.R.; Kim, Y.S.; Choi, W.S.; Jeong, R.D. Antifungal effect of non-thermal atmospheric plasma and its application for control of postharvest Fusarium oxysporum decay of paprika. Food Control 2019, 98, 245-252. [CrossRef]

51. Avramidis, G.; Stuwe, B.; Wascher, R.; Bellmann, M.; Wieneke, S.; von Tiedemann, A. Fungicidal effects of an atmospheric pressure gas discharge and degradation mechanisms. Surf. Coat. Technol. 2010, 205, S405-S408. [CrossRef]

52. Moisan, M.; Barbeau, J.; Moreau, S.; Pelletier, J.; Tabrizian, M.; Yahia, L.H. Low-temperature sterilization using gas plasmas: A review of the experiments and an analysis of the inactivation mechanisms. Int. J. Pharm. 2001, 226, 1-21. [CrossRef]

53. Dzimitrowicz, A.; Jamróz, P.; Nowak, P. Sterylizacja za pomocą niskotemperaturowej plazmy, generowanej w warunkach ciśnienia osmotycznego. Post. Mikrobiol. 2015, 54, 195-200. 